\title{
A Study on antioxidant properties of Gyrodon lividus
}

\author{
Celal Bal \\ Gaziantep University, Oğuzeli Vocational High School, 27900, Oğuzeli, Gaziantep, Turkey
}

Corresponding author: bal@gantep.edu.tr

\begin{abstract}
It is possible to classify mushrooms as edible, inedible and poisonous. The present study aimed to determine the antioxidant potential of Gyrodon lividus an edible mushroom species. Thus, total antioxidant status (TAS) and total oxidant status (TOS) of mushroom ethanol extracts were determined and oxidative stress index (OSI) was calculated based on TAS and TOS findings. Based on the study findings, the TAS value was $2.077 \pm 0.087$, TOS value was $13.465 \pm 0.213$ and OSI level was $0.651 \pm 0.037$. Thus, it was suggested that the mushroom had antioxidant potential, however G. lividus collected in Burdur province should be consumed with care due to the high oxidative stress levels.
\end{abstract}

Keywords: Gyrodon lividus, edible mushrooms, antioxidant, oxidant, oxidative stress.

\section{Özet}

Mantarları yenilebilir, yenmez ve zehirli olarak sınıflandırmak mümkündür. Bu çalışma, yenilebilir mantar türlerinden Gyrodon lividus'un antioksidan potansiyelini belirlemeyi amaçlamıştır. Bu nedenle, mantarın etanol ekstrelerinin toplam antioksidan durumu (TAS) ve toplam oksidan durumu (TOS) belirlenerek, TAS ve TOS bulgularına göre oksidatif stres indeksi (OSI) hesaplanmıştır. Araştırma bulgularına göre TAS değeri 2.077 \pm 0.087 , TOS değeri $13.465 \pm 0.213$ ve OSI değeri $0.651 \pm 0.037$ olarak belirlenmiştir. Bu yüzden mantarın antioksidan potansiyele sahip olduğu tespit edilmiştir, fakat Burdur ilinden toplanan G. lividus'un yüksek oksidatif stres düzeyleri nedeniyle dikkatli tüketilmesi önerilmektedir.

Anahtar Kelimeler: Gyrodon lividus, yenilebilir mantarlar, antioksidan, oksidan, oksidatif stres.

\section{Introduction}

Mushrooms are among the natural nutrient resources for humankind. The increase in mushroom consumption was associated with their vitamins and protein content, as well as the pleasant taste and aroma of the edible mushrooms. They are also significant among natural products due to their strong antioxidant properties and the fact that they are natural products, which do not contain any pesticides (Gürgen et al. 2018, Sevindik et al. 2018a).

It is also known that mushrooms have strong antioxidant capacity in addition to their nutritional properties. Furthermore, mushrooms were reported to possess anticarcinogen, antimicrobial, DNA protective, anti-inflammatory and antiallergic effects in addition to their antioxidant properties (Park et al. 2014, Akgül et al., 2016; Lima et al. 2016, Taofiq et al. 2016, Y1lmaz et al. 2016, Sevindik et al. 2017). 
The present study aimed to determine total antioxidant capacity, total oxidant capacity and oxidative stress index of Gyrodon lividus (Bull.) Sacc. mushroom ethanol extract. Thus, antioxidant potential of the mushroom was determined and its consumption as a natural antioxidant source was assessed.

\section{Material and Method}

In the autumn of 2017, G. lividus samples were collected from sweetgum forest protected area in Burdur Province. The morphological and ecological characteristics of the samples were noted and basidiomata photographed in natural habitats. After field studies, the specimens were taken to the laboratory. Microcharacters were observed with a light microscope. For microscopic analyses, dried material was rehydrated in distilled water and 5\% $\mathrm{KOH}$, and subsequently stained in Congo Red. Identification of the specimens was based on Hayward and Thiers (1984), Kibby (2012) and Sesli et al. (2015) (Figure 1). Mushroom specimens were dried in the laboratory under suitable conditions. Dried mushroom samples were extracted with ethanol (EtOH) in a Soxhlet extractor (Gerhardt EV 14). The obtained extracts were concentrated using a rotary evaporator (Heidolph Laborator 4000 Rotary Evaporator).

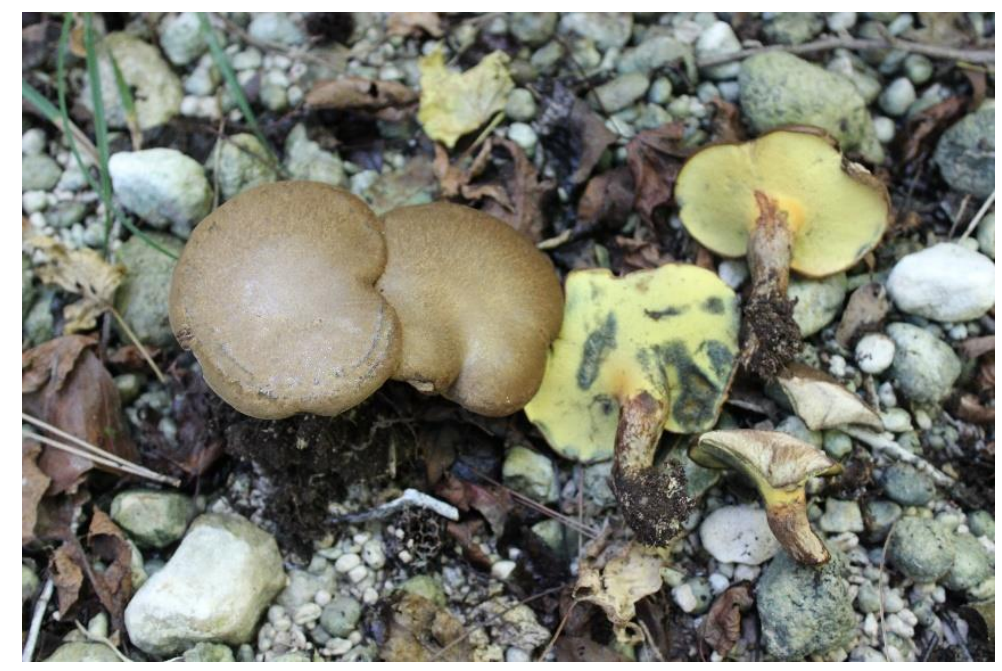

Figure 1. Gyrodon lividus (Bull.) Sacc.

Following the extraction, Rel Assay brand TAS kits were used to determine the total antioxidant status of mushroom extracts and the findings were calculated as mmol/L. Rel Assay brand TOS kits were used to determine the total oxidant status and the findings were calculated as $\mu \mathrm{mol} / \mathrm{L}$. Trolox was used for TAS calibrator and hydrogen peroxide was used as TOS calibrator (Erel 2004, Erel 2005). To determine the OSI value, the TOS and TAS units were equalized and OSI was calculated with the following formula.

$$
\text { OSI } \frac{\text { TOS, } \mu \mathrm{mol} \mathrm{H}_{2} \mathrm{O}_{2} \text { equiv./L }}{\text { TAS, mmol Trolox equiv./L } \times 10}
$$

\section{Results and Discussion}

In recent years, edible mushrooms are at the center of attention as commercial antioxidant resources. They can be used directly in improvement of antioxidant defenses via nutritional supplements to reduce oxidative stress levels (Kozarski et al. 2015). In the present study, TAS, TOS and OSI of G. lividus mushroom ethanol extracts were determined and the findings are presented in Table 1. 
Table 1. TAS, TOS and OSI values of Gyrodon lividus

\begin{tabular}{llll}
\hline & TAS & TOS & OSI \\
\hline & & & \\
G. lividus & $2.077 \pm 0.087$ & $13.465 \pm 0.213$ & $0.651 \pm 0.037$ \\
\hline
\end{tabular}

Literature review revealed that no previous studies were conducted to determine the total antioxidant status, total oxidant status and oxidative stress index of G. lividus mushroom. In previous studies, it was determined that the TAS values of Auricularia auricula and Trametes versicolor mushrooms were 1.010 and 0.820, respectively and the TOS values for the same mushrooms were 23.910 and 17.760, respectively, and OSI were 2.367 and 2.166, respectively (Akgül et al. 2017). In the present study, it was determined that G. lividus mushroom had a higher TAS value when compared to that of the $A$. auricula and T. versicolor mushrooms. It was also found that the TOS and OSI values were also lower than those of A. auricula and T. versicolor fungi. In previous studies, it was also determined that the TAS value of Pholiota limonella was 2.378, the TOS value of the same mushroom was 4.742 and the OSI value was 0.199 . The TAS value of Cyclocybe cylindracea was 4.325 , the TOS value of the same mushroom was 21.109 and the OSI value was 0.488 (Sevindik et al. 2018b, Sevindik et al. 2018c). When compared to the results of the above-mentioned studies, it was determined in the present study that $G$. lividus mushroom had a lower TAS value. It was determined that the TOS value of G. lividus mushroom was higher than that of $P$. limonella and lower than that of $C$. cylindracea. It was also found that $G$. lividus mushroom had higher OSI values when compared to the mushrooms studies in the abovementioned studies. It was thought that the differences in antioxidant and oxidant capacities between the mushrooms were due to the differences between mushroom species. It was determined that G. lividus mushroom inhibited oxidant compounds better than P. limonella and C. cylindracea mushrooms, while inhibited the same compounds lower than A. auricula and T. versicolor mushrooms. Thus, it was determined that $G$. lividus mushroom exhibited antioxidant potential. It was also determined that the mushroom had normal oxidant compound levels. However, due to its high oxidative stress levels, it was advised to consume the mushroom with care.

\section{Conclusion}

In the present study conducted to determine the antioxidant potential of G. lividus mushroom, the mushroom was determined to have antioxidant potential. Also, limited consumption of G. lividus, an edible mushroom, collected in Burdur province was advised due to its high oxidative stress levels.

\section{Acknowledgment}

I would like to express my gratitude to Dr. Mustafa SEVINDIK and Dr. Ömer F. ÇOLAK for their valuable contributions to the present study.

\section{References}

Akgul, H., Sevindik, M., Coban, C., Alli, H., Selamoglu, Z. (2017). New Approaches in Traditional and Complementary Alternative Medicine Practices: Auricularia auricula and Trametes versicolor. J Tradit Med Clin Natur, 6(239): 1000239.

Akgül, H., Nur, A.D., Sevindik, M., Doğan, M. (2016). Tricholoma terreum ve Coprinus micaceus'un bazı biyolojik aktivitelerinin belirlenmesi. Artvin Çoruh Üniversitesi Orman Fakültesi Dergisi, 17(2): 158162. 
Erel, O. (2004) A novel automated direct measurement method for total antioxidant capacity using a new generation, more stable ABTS radical cation. Clinical biochemistry, 37(4): 277- 285.

Erel, O. (2005) A new automated colorimetric method for measuring total oxidant status. Clinical biochemistry, 38(12): 1103-1111.

Gürgen, A., Yildiz, S., Can, Z., Tabbouche, S., Kiliç, A.O. (2018). Antioxidant, Antimicrobial and Anti-Quorum Sensing Activities of Some Wild and Cultivated Mushroom Species Collected From Trabzon,Turkey. Fresenius Environmental Bulletin, 27(6): 4120-4131.

Hayward, D., Thiers, H. D. (1984). Gyrodon lividus in California. Mycologia, 76(3): 573-575.

Kibby, G. (2012): British Boletes with keys to species. 79 p. London.

Kozarski, M., Klaus, A., Jakovljevic, D., Todorovic, N., Vunduk, J., Petrović, P., Niksic, M., Vrvic, M.M., Van Griensven, L. (2015). Antioxidants of edible mushrooms. Molecules, 20(10): 19489-19525.

Lima, C. U., Gris, E. F., Karnikowski, M. G. (2016). Antimicrobial properties of the mushroom Agaricus blazeiintegrative review. Revista Brasileira de Farmacognosia, 26(6): 780-786.

Park, Y. K., Lee, H. B., Jeon, E. J., Jung, H. S., Kang, M. H. (2004). Chaga mushroom extract inhibits oxidative DNA damage in human lymphocytes as assessed by comet assay. Biofactors, 21(1-4): 109-112.

Sesli, E., Contu, M., Jordi, V, Moreau, P. A., Battistin, E. (2015). Taxonomic studies on some agaricoid and boletoid fungi of Turkey. Turkish Journal of Botany, 39(1): 134-146.

Sevindik, M., Akgul, H., Bal, C. (2017a). Determination of Oxidative Stress Status of Ompholatus olearius Gathered from Adana and Antalya Provinces in Turkey. Sakarya Üniversitesi Fen Bilimleri Enstitüsü Dergisi, 21(3): 324-327.

Sevindik, M., Akgul, H., Korkmaz, A.I., Sen, I. (2018a). Antioxidant Potantials of Helvella leucomelaena and Sarcosphaera coronaria. J Bacteriol Mycol Open Access, 6(2): 00173.

Sevindik, M., Akgul, H., Bal, C., Altuntas, D., Korkmaz, A.I., Dogan, M. (2018b). Oxidative Stress and Heavy Metal Levels of Pholiota limonella Mushroom Collected from Different Regions. Current Chemical Biology, DOI: 10.2174/2212796812666180503151759

Sevindik, M., Akgul, H., Bal, C., Selamoglu, Z. (2018c). Phenolic Contents, Oxidant/Antioxidant Potential and Heavy Metal Levels in Cyclocybe cylindracea. Indian Journal of Pharmaceutical Education and Research, 52(3):437-441.

Taofiq, O., Martins, A., Barreiro, M. F., Ferreira, I. C. (2016). Anti-inflammatory potential of mushroom extracts and isolated metabolites. Trends in Food Science \& Technology, 50: 193-210.

Yılmaz, A., Yıldız, S., Kılıç, C., Can, Z. (2016). Total phenolics, flavonoids, tannin contents and antioxidant properties of Pleurotus ostreatus cultivated on different wastes and sawdust. International Journal of Secondary Metabolite (IJSM), 4(1):1-9

Submitted: 18.05 .2018

Accepted: 08.06.2018 